\title{
Nimesulide Based Novel Glycolamide Esters: Their Design, Synthesis, and Pharmacological Evaluation
}

\author{
Kavitha Kankanala, ${ }^{1,2}$ Vangala Ranga Reddy, ${ }^{3}$ Yumnam Priyadarshini Devi, \\ Lakshmi Narasu Mangamoori, ${ }^{4}$ Khagga Mukkanti, ${ }^{1}$ and Sarbani Pal ${ }^{2}$ \\ ${ }^{1}$ Centre for Chemical Science and Technology, IST, JNTUH, Kukatpally, Hyderabad, Andhra Pradesh 500085, India \\ ${ }^{2}$ Department of Chemistry, MNR Degree and PG College, Kukatpally, Hyderabad, Andhra Pradesh 500085, India \\ ${ }^{3}$ Dr. Reddy's Laboratories Limited, Integrated Product Development, Bachupally, Hyderabad, Andhra Pradesh 500055, India \\ ${ }^{4}$ Centre for Biotechnology, IST, JNTUH, Kukatpally, Hyderabad, Andhra Pradesh 500085, India
}

Correspondence should be addressed to Sarbani Pal; sarbani277@yahoo.com

Received 16 May 2013; Accepted 31 July 2013

Academic Editor: Weiguo Dai

Copyright (c) 2013 Kavitha Kankanala et al. This is an open access article distributed under the Creative Commons Attribution License, which permits unrestricted use, distribution, and reproduction in any medium, provided the original work is properly cited.

The nimesulide based novel glycolamide esters were designed and synthesized for the first time via a three-step method starting from nimesulide. Structures of the synthesized compounds were confirmed by spectroscopic analysis. All the synthesized compounds were examined for their cytotoxic effects in vitro, some of which showed significant cytotoxic activities against HCT-15 human colon cancer cell line.

\section{Introduction}

Cancer is the second leading cause of death [1] worldwide after cardiovascular diseases, according to WHO. Indeed, lung, breast, stomach, liver, and colorectal cancers cause the most cancer deaths worldwide each year, and therefore discovery and development of suitable agents to treat various types of cancer are highly desirable.

Over the years, glycolamide esters have attracted particular attention as prodrugs of many pharmaceutically important molecules [2-4] because of their ability to undergo quick cleavage in human plasma to deliver the parent drugs. These include glycolamide esters of aspirin [5], ibuprofen [6], niflumic acid [7], and scutellarin [8] that are reported as biolabile prodrugs of these drugs. However, studies have suggested that the rate of plasma catalyzed hydrolysis of glycolamide esters can be altered with the change of substituents on amide nitrogen atom [9-12]. For example, monosubstituted $\left(-\mathrm{CO}_{2} \mathrm{CH}_{2} \mathrm{CONHR}\right)$ or unsubstituted $\left(-\mathrm{CO}_{2} \mathrm{CH}_{2} \mathrm{CONH}_{2}\right)$ glycolamide esters were found to be more resistant than $\mathrm{N}, \mathrm{N}$-disubstituted glycolamide esters $\left(-\mathrm{CO}_{2} \mathrm{CH}_{2} \mathrm{CONRR}{ }^{\prime}\right)$. Indeed, some of these stable prodrugs were found to behave like new chemical entities (NCEs) and have shown promising pharmacological effects comparable to the parent drugs. For example, Colfenamate (Figure 1), a glycolamide ester, has shown good analgesic and anti-inflammatory properties [13]. These observations and our interest in novel cytotoxic agents prompted us to synthesize and evaluate a library of new glycolamide esters A (Figure 1).

The design of our target molecules $\mathbf{A}$ was based on the structural modifications of nimesulide [14-20]. We anticipated that combining the structural features of nimesulide and glycolamide esters in a single molecule may afford novel template for the design and synthesis of new anticancer agents. Notably, the cyclooxygenase-2 (COX-2) inhibitor nimesulide is known to possess anticancer properties [21, 22] whereas the glycolamide esters are known to impart favorable pharmacological properties. Herein we report the synthesis and in vitro cytotoxic effects of a series of novel glycolamide esters A derived from nimesulide. To the best of our knowledge, synthesis and pharmacological evaluation of glycolamide esters derived from nimesulide are not known in the literature.

\section{Experimental}

2.1. General Methods. Melting points were determined by open glass capillary method on a Cintex melting point 


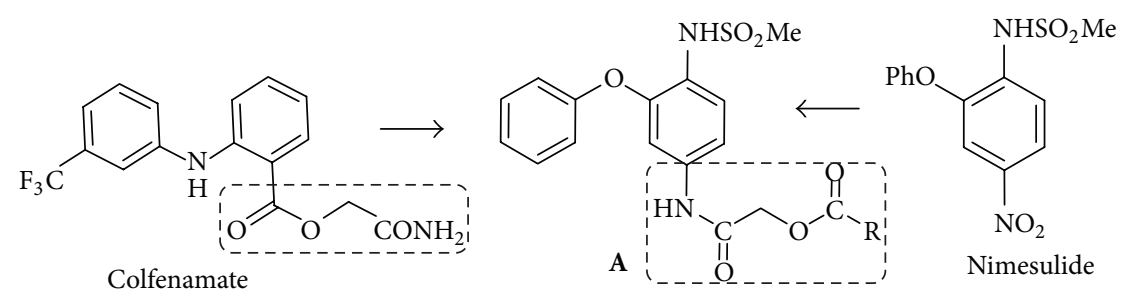

FIgURE 1: Known glycolamide ester Colfenamate, COX-2 inhibitor nimesulide, and new glycolamide esters A.

apparatus and are uncorrected. IR spectra were recorded on a Perkin-Elmer spectrometer using $\mathrm{KBr}$ pellets. ${ }^{1} \mathrm{HNMR}$ spectra were recorded on a Bruker ACF-300 machine and a Varian 300 and $400 \mathrm{MHz}$ spectrometer using $\mathrm{CDCl}_{3}$ or DMSO- $d_{6}$, with reference to tetramethylsilane as an internal reference. ${ }^{13} \mathrm{CNMR}$ spectra were recorded on a $75 \mathrm{MHz}$ spectrometer. Elemental analyses were performed by Varian $3 \mathrm{LV}$ analyzer series $\mathrm{CHN}$ analyzer. Mass spectra were recorded on a Jeol JMC D-300 instrument by using electron ionization at $70 \mathrm{ev}$. All reactions were monitored by TLC on precoated silica gel plates. Column chromatography was performed on 100-200 mesh silica gel (SRL, India) using 10-20 times (by weight) of the crude product. All the carboxylic acids used are commercially available.

2.2. Synthesis of 2-Chloro-N-(4-methanesulfonylamino-3-phenoxy-phenyl)-acetamide (2). $3.6 \mathrm{mmol}(1 \mathrm{~g})$ of compound (1) was taken into a round bottomed flask. To this $20 \mathrm{~mL}$ of $\mathrm{CHCl}_{3}$ and $0.6 \mathrm{~mL}$ of $\mathrm{Et}_{3} \mathrm{~N}$ were added. This mixture was stirred and then cooled to $0^{\circ} \mathrm{C}$ using an ice bath. To this mixture $3.6 \mathrm{mmol}(0.5 \mathrm{~mL})$ of $\alpha$-chloroacetyl chloride was added drop wise. The mixture was then cooled to room temperature and stirring was continued for an additional 30 minutes. After completion of the reaction as indicated by TLC, the mixture was diluted with $10-15 \mathrm{~mL}$ of cold water, which was then extracted with $\mathrm{CHCl}_{3}(3 \times 20 \mathrm{~mL})$. The organic layers were collected, combined, washed with water, dried over anhydrous $\mathrm{Na}_{2} \mathrm{SO}_{4}$, filtered, and concentrated under reduced pressure. The crude product obtained was recrystallised from aqueous $\mathrm{EtOH}$ to give the titled compound as an off-white solid; $\mathrm{mp} 135-136^{\circ} \mathrm{C} ; R_{f}: 0.45$ $\left(\mathrm{CHCl}_{3}\right.$ : ethyl acetate $\left.=9: 1\right) ; \mathrm{IR}(\mathrm{KBr}) \nu_{\max } / \mathrm{cm}^{-1}: 3325,3265$, $1665,1611,1589 ;{ }^{1} \mathrm{H}$ NMR $\left(400 \mathrm{MHz}, \mathrm{DMSO}-d_{6}\right): \delta 10.30$ (s, $1 \mathrm{H}, \mathrm{NHCO}, \mathrm{D}_{2} \mathrm{O}$ exchangeable), $9.25\left(\mathrm{~s}, 1 \mathrm{H}, \mathrm{NH}, \mathrm{D}_{2} \mathrm{O}\right.$ exchangeable), 7.50-7.40 (m, $2 \mathrm{H}), 7.38-7.26(\mathrm{~m}, 2 \mathrm{H}), 7.21-7.14$ $(\mathrm{m}, 2 \mathrm{H}), 7.10(d, J 8.8 \mathrm{~Hz}, 2 \mathrm{H}), 4.20(\mathrm{~s}, 2 \mathrm{H}), 3.00(\mathrm{~s}, 3 \mathrm{H})$; ${ }^{13} \mathrm{C}$ NMR $\left(100 \mathrm{MHz}, \mathrm{CDCl}_{3}\right): \delta$ 164.7, 155.4, 148.2, 134.8, 130.2, 124.7, 124.4, 123.1, 118.8, 115.6, 110.1, 52.7, 39.4; MS $(\mathrm{m} / \mathrm{z}): 355$ $\left(\mathrm{M}^{+}, 100 \%\right), 357.2\left(\mathrm{M}^{+}+2,33 \%\right)$; Elemental analysis: found: $\mathrm{C}$, $50.84 ; \mathrm{H}, 4.02 ; \mathrm{N}, 7.73 ; \mathrm{C}_{15} \mathrm{H}_{15} \mathrm{ClN}_{2} \mathrm{O}_{4} \mathrm{~S}$ requires $\mathrm{C}, 50.78 ; \mathrm{H}$, $4.26 ; \mathrm{N}, 7.90$.

2.3. General Procedure for the Synthesis of Glycolamide Esters $(4 a-l)$. A mixture of $N$-chloroacetamide $(0.01 \mathrm{~mol})$, an appropriate acid $(0.01 \mathrm{~mol})$, potassium iodide $(0.001 \mathrm{~mol})$, triethylamine $(0.011 \mathrm{~mol})$, and $\mathrm{N}, \mathrm{N}$-dimethylformamide $(10 \mathrm{~mL})$ was stirred for $15-45 \mathrm{~min}$ (depending on the acid derivative) at $90^{\circ} \mathrm{C}$. The reaction mixture was poured into water $(50 \mathrm{~mL})$ and extracted with ethyl acetate $(3 \times 50 \mathrm{~mL})$. The combined organic extracts were washed with $2 \%$ aqueous sodium bicarbonate $(50 \mathrm{~mL})$ and water $(3 \times 50 \mathrm{~mL})$. The organic layer was collected, dried over anhydrous $\mathrm{Na}_{2} \mathrm{SO}_{4}$, and evaporated under reduced pressure. The crude product obtained was purified by column chromatography to get the corresponding glycolamide esters (4a-1).

2.4. MTT Assay for Cytotoxicity. The viability of the cells was assessed by MTT [3, 4, 5-dimethylthiazol-2-yl)-2-5diphenyltetrazolium bromide] assay, which is based on the reduction of MTT by the mitochondrial dehydrogenase of intact cells to a purple formazan product. Etoposide, a known anticancer drug, was used as a reference compound in this assay. Cells $\left(1 \times 10^{4}\right)$ were plated in a 96-well plate. After $24 \mathrm{~h}$, they were treated with different concentrations $(0-25 \mu \mathrm{M})$ of different test compounds diluted appropriately with culture media for $48 \mathrm{~h}$. Cells grown in media containing equivalent amount of DMSO served as positive control and cells in medium without any supplementation were used as negative control. After the treatment, media containing compound were carefully removed by aspiration. $100 \mu \mathrm{L}$ of $0.4 \mathrm{mg} / \mathrm{mL}$ MTT in PBS was added to each well and incubated in the dark for $4 \mathrm{~h} .100 \mu \mathrm{L}$ of DMSO was added to each well and kept in an incubator for $4 \mathrm{~h}$ for dissolution of the formed formazan crystals. The amount of formazan was determined by measuring the absorbance at $540 \mathrm{~nm}$ using an ELISA plate reader. The data were presented as percent dead cells, whereas absorbance from nontreated control cells was defined as $100 \%$ live cells. The percent of dead cells was plotted ( $y$ axis) against concentration ( $x$-axis) of compounds, where $\mathrm{IC}_{50}$ values could be interpolated from the graph.

\section{Results and Discussion}

The key starting material, that is, 2-chloro- $\mathrm{N}$-(4-methanesulfonylamino-3-phenoxy-phenyl)-acetamide (2) required for our synthesis was prepared via chloroacetylation of $\mathrm{N}$-(4-amino-2-phenoxyphenyl) methane sulfonamide [14] (1, obtained from nimesulide) in dry $\mathrm{CHCl}_{3}$ in presence of $\mathrm{Et}_{3} \mathrm{~N}$ (Scheme 1).

The chlorocompound 2 was well characterized by using MS, IR, ${ }^{1} \mathrm{H}$, and ${ }^{13} \mathrm{C}$ NMR spectroscopic techniques. For example, the IR spectrum showed absorption at $1665(\mathrm{C}=\mathrm{O}$ stretching), 3325, and $3265 \mathrm{~cm}^{-1}$ ( $\mathrm{NH}$ stretching) whereas ${ }^{1}$ HNMR spectrum recorded in DMSO- $d_{6}$ displayed two singlets at $\delta 4.20$ and $2.96 \mathrm{ppm}$ due to $\mathrm{CH}_{2}$ and $\mathrm{CH}_{3}$ groups, respectively. The presence of $\mathrm{NH}$ groups was further 


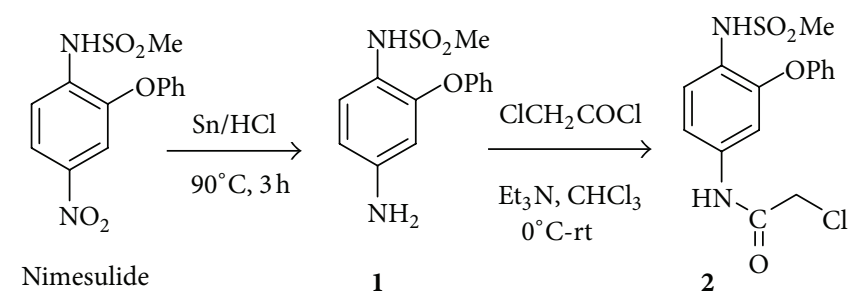

SCHEME 1: Synthesis of key starting material 2.
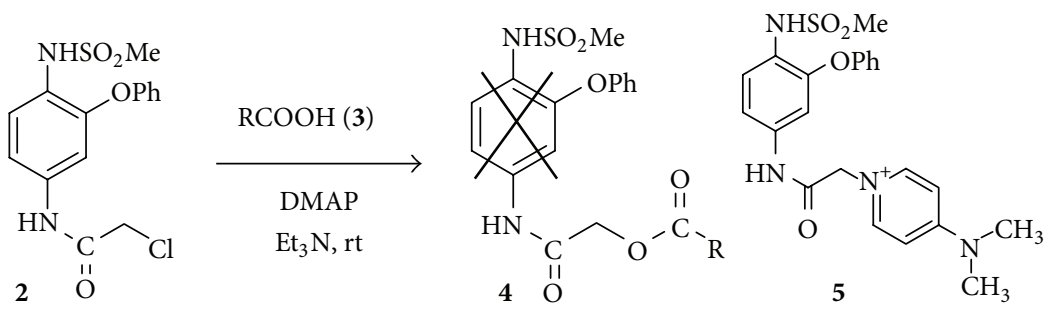

Scheme 2: The reaction of chloro compound 2 with carboxylic acids 3.

indicated by the disappearance of two peaks at $\delta 10.46$ and $9.22 \mathrm{ppm}$ in $\mathrm{D}_{2} \mathrm{O}$ exchange experiment. Moreover, the ${ }^{13} \mathrm{C}$ signals at $164.7,52.7$, and $39.4 \mathrm{ppm}$ indicated the presence of amide carbonyl, $\mathrm{CH}_{2}$ and $\mathrm{CH}_{3}$ groups, respectively. Having prepared the starting material 2, we then treated this chloroderivative with commercially available carboxylic acids in the presence of catalytic amount of $N, N$-dimethyl4-aminopyridine [9] using $\mathrm{Et}_{3} \mathrm{~N}$ as a base (Scheme 2). To our surprise, instead of the desired glycolamide esters (4) we isolated a white solid with the melting point $264-265^{\circ} \mathrm{C}$ irrespective of acid partner employed. Based on the spectral data (IR, ${ }^{1} \mathrm{H} \&{ }^{13} \mathrm{C} \mathrm{NMR}$, and MS) the isolated solid was confirmed as 2-(4-dimethylamino-pyridin-1-yl)- $N$-(4-methanesulfonylamino-3-phenoxy-phenylcarbamoyl)-methyl ester (5). It was evident that DMAP reacted better than the acid 3 with the chloro compound 2 perhaps due to its predominant role as a nucleophile rather than a base under the reaction conditions employed. We therefore decided to omit its use in our subsequent studies.

We then performed the reaction of $\mathbf{2}$ with $\mathbf{3}$ under a modified reaction conditions, that is, in the presence of potassium iodide and $\mathrm{Et}_{3} \mathrm{~N}$. To our satisfaction the desired product 4 was isolated in good yields and the results are summarized in Table 1 . It is evident from Table 1 that both aliphatic and aromatic acids participated well in the present reaction and a range of nimesulide based glycolamide esters (4) were prepared by using this methodology. All the compounds synthesized were well characterized by spectral data. For example, compound 4a showed IR signals at 1742 (ester carbonyl) and $1677 \mathrm{~cm}^{-1}$ (amide carbonyl), respectively. The appearance of two singlets at $\delta 2.20$ for $3 \mathrm{H}$ and $\delta 4.64$ for $2 \mathrm{H}$ in ${ }^{1} \mathrm{H}$ NMR spectrum of $\mathbf{4 a}$ confirmed the presence of $-\mathrm{COMe}$ and $\mathrm{CH}_{2}$ groups, respectively. In ${ }^{13} \mathrm{C} \mathrm{NMR}$ appearance of 15 signals was highly consistent with the 15 nonequivalent carbon atoms of the compound 4a. Moreover, the ester and amide carbonyls appear at $\delta 169.9$ and $165.5 \mathrm{ppm}$, whereas the $\mathrm{CH}_{2}$ group appeared at $\delta 62.4 \mathrm{ppm}$.
All the glycolamide esters 4 synthesized were tested in vitro against HCT-15 human colon cancer cell line based on an MTT [3-(4,5-dimethylthiazol-2-yl)-2,5-diphenyltetrazolium bromide] assay (Table 2) [23]. Defined as a cancer from uncontrolled cell growth in the colon or rectum (parts of the large intestine), or in the appendix, colon cancer (commonly known as colorectal cancer or bowel cancer) is the third most commonly diagnosed cancer in the world. It was estimated in 2008 that worldwide 1.23 million new cases of colorectal cancer were clinically diagnosed, and that it killed 608,000 people [24]. This prompted us to focus on colon cancer. In our present assay, the percentage of cell death was measured for each compound at various concentrations and finally the $\mathrm{IC}_{50}$ (half maximal inhibitory concentration) values were determined to measure the cytotoxic activities. The $\mathrm{IC}_{50}$ is inversely proportional to the cytotoxicity of a compound; that is, the lower the $\mathrm{IC}_{50}$ value is, the higher the activity is. In general, most of the compounds were found to be active against the HCT-15 colon cancer cell line at $25 \mu \mathrm{M}$. Notable among them are 4d (Entry 4, Table 2), 4f (Entry 6, Table 2), 4g (Entry 7, Table 2), 4i (Entry 9, Table 2), 4j (Entry 10, Table 2), 4k (Entry 11, Table 2), and $\mathbf{4 l}$ (Entry 12, Table 2) that showed $>40 \%$ inhibition at $25 \mu \mathrm{M}$. It is evident that an aryl group attached to the ester carbonyl moiety was generally more favorable than an alkyl group for activity (e.g., $\mathbf{4 a - b}$ versus $\mathbf{4 c - f}$ ). While insertion of an olefin moiety between the ester carbonyl and the aryl group was tolerated (e.g., 4g), a naphthylmethyl group (e.g., 4h) attached to the carbonyl moiety decreased the activity. However, a benzyl group having substituent at $p$ - or $o$-position (e.g. $\mathbf{4 j - 1}$ ) was favorable for activity. A graphical presentation of in vitro cytotoxic activities of compound $\mathbf{4 l}$ against HCT-15 human colon cancer cell line is shown in Figure 2 . The $\mathrm{IC}_{50}$ values of most active compounds, that is, $4 \mathbf{j}, 4 \mathbf{k}$, and $\mathbf{4 l}$, were found to be $24.40,22.40$, and $18.92 \mu \mathrm{M}$, respectively. Thus, the compound $4 \mathbf{l}$ (calculated average $\log P=2.83 \pm 0.46$ and average $\log S=-6.04$ versus $1.75 \pm 0.26$ and -4.24 , resp., of compound 1 [25]) was identified as the best active compound 
TABLE 1: Synthesis of nimesulide based glycomide esters $4 .{ }^{\mathrm{a}}$

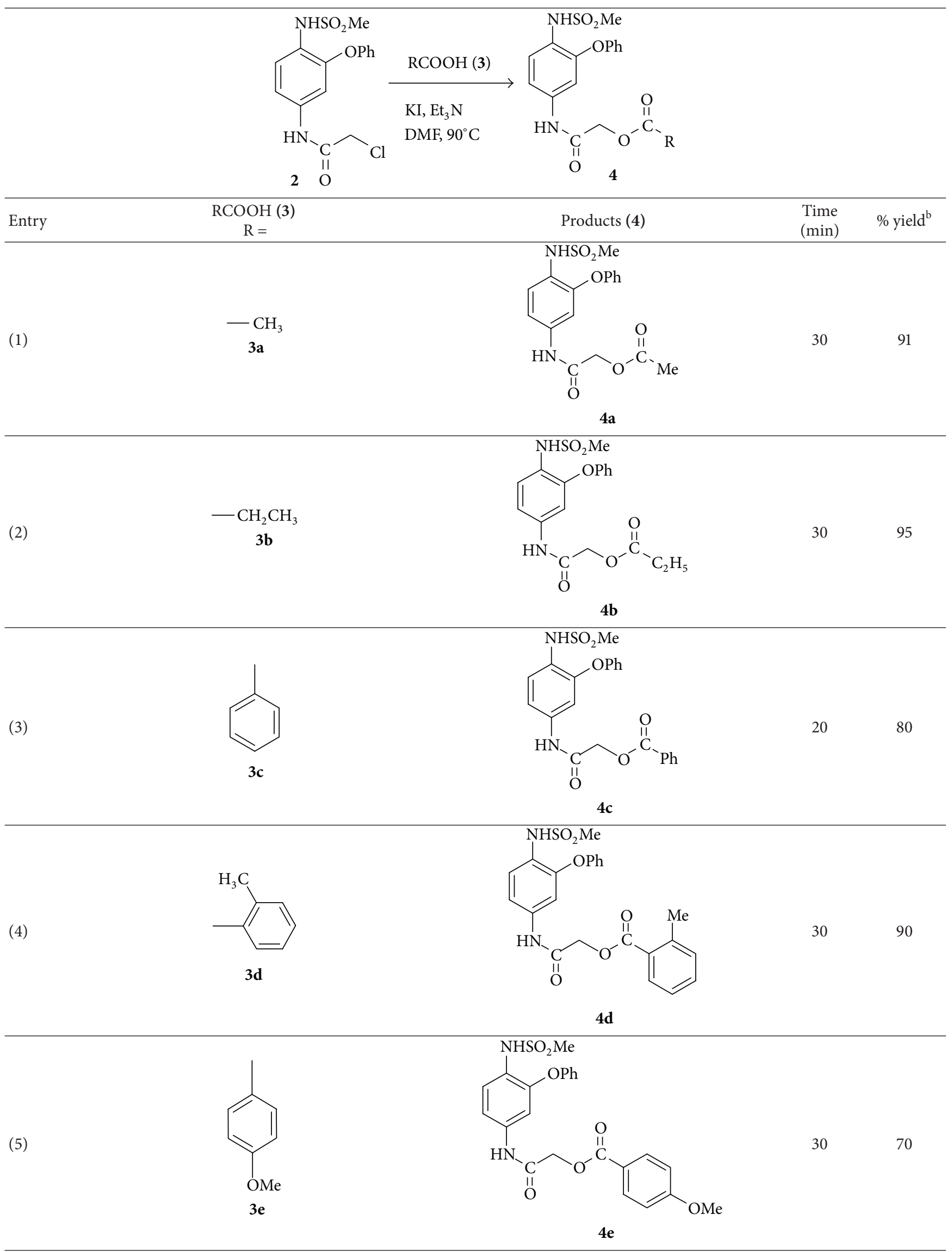


TABle 1: Continued.

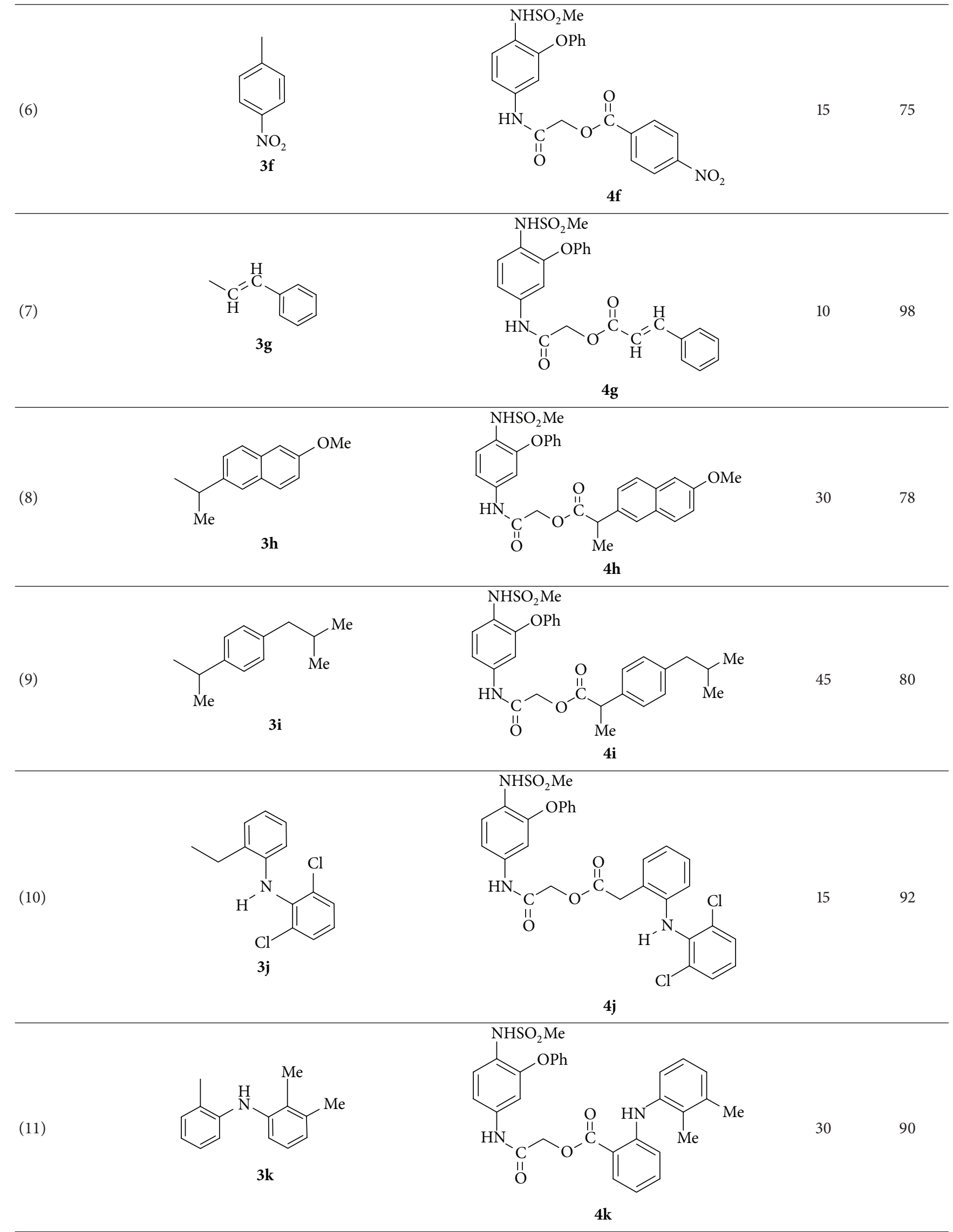


TABle 1: Continued.<smiles>CC(=O)Oc1ccccc1C</smiles>

31<smiles>CC(=O)Oc1ccccc1C(=O)OCC(=O)Nc1ccc(NS(C)(=O)=O)c(Oc2ccccc2)c1</smiles>

41

${ }^{\mathrm{a}}$ All the reactions were performed using chlorocompound $2(0.01 \mathrm{mmol})$ and acid $3(0.01 \mathrm{~mol})$ in the presence of $\mathrm{NaI}(0.001 \mathrm{~mol}), \mathrm{Et}{ }_{3} \mathrm{~N}(0.011 \mathrm{mmol})$, and DMF $(15 \mathrm{~mL})$ at $90^{\circ} \mathrm{C}$.

${ }^{\mathrm{b}}$ Isolated yield.

TABLE 2: In vitro cytotoxic activity of compound 4 against HCT-15 human colon cancer cell line.

\begin{tabular}{|c|c|c|c|c|c|c|c|}
\hline \multirow{2}{*}{ Entry } & \multirow{2}{*}{ Compounds } & \multicolumn{5}{|c|}{$\%$ of cell death at various concentrations ${ }^{\mathrm{a}}$} & \multirow{2}{*}{$\mathrm{IC}_{50}(\mu \mathrm{M})$} \\
\hline & & $1 \mu \mathrm{M}$ & $2 \mu \mathrm{M}$ & $5 \mu \mathrm{M}$ & $10 \mu \mathrm{M}$ & $25 \mu \mathrm{M}$ & \\
\hline 1 & $4 a$ & 0.94 & 6.89 & 8.15 & 8.77 & 20.30 & n.d. \\
\hline 2 & $4 b$ & 0.62 & 7.20 & 7.50 & 18.50 & 28.50 & n.d. \\
\hline 3 & $4 c$ & 0.31 & 12.5 & 2.50 & 7.52 & 31.00 & n.d. \\
\hline 4 & $4 d$ & 3.43 & 4.53 & 21.69 & 35.78 & 49.38 & n.d. \\
\hline 5 & $4 e$ & 1.88 & 6.58 & 13.16 & 17.55 & 28.80 & n.d. \\
\hline 6 & $4 \mathrm{f}$ & 5.88 & 14.46 & 20.22 & 25.00 & 42.40 & n.d. \\
\hline 7 & $4 \mathrm{~g}$ & 6.00 & 7.96 & 14.46 & 18.62 & 41.91 & n.d. \\
\hline 8 & $4 h$ & 0.31 & 7.52 & 8.77 & 12.20 & 19.40 & n.d. \\
\hline 9 & $4 i$ & 7.35 & 12.37 & 14.95 & 16.29 & 48.89 & n.d. \\
\hline 10 & $4 j$ & 6.74 & 9.43 & 25.61 & 35.90 & 51.22 & $24.40 \pm 0.14$ \\
\hline 11 & $4 k$ & 0 & 5.96 & 12.20 & 30.70 & 55.79 & $22.40 \pm 1.31$ \\
\hline 12 & 41 & 21.69 & 21.93 & 24.50 & 30.02 & 66.05 & $18.92 \pm 0.09$ \\
\hline
\end{tabular}

${ }^{a}$ All the values are the average of the experiments done in triplicates. Etoposide $\left(\mathrm{IC}_{50}=9.85 \mu \mathrm{M}\right)$ was used as a reference compound. n.d.: not done.

in this series. Notably, the $\mathrm{IC}_{50}$ value of nimesulide was found to be $>150 \mu \mathrm{M}[26]$ whereas its reduced product did not show significant activities.

Since the colon cancer is common in developed countries, the present class of glycolamide esters has medicinal value. It is worthy to mention that nimesulide is a banned drug in many countries because of its potential liver toxicity. The observed liver toxicity of nimesulide has often been linked to its uncoupling effects on mitochondria and study has shown that nimesulide exerts this effect via a protonophoretic mechanism as well as oxidation of mitochondrial NADH and $\mathrm{NADPH}$ [27]. The nitro group of nimesulide was thought to be responsible for its protonophoretic and $\mathrm{NAD}(\mathrm{P}) \mathrm{H}$ oxidizing properties as chemical reduction of $-\mathrm{NO}_{2}$ to $-\mathrm{NH}_{2}$ completely suppressed these activities. Thus, the present class of compounds that does not contain a nitro group on the $\mathrm{NHSO}_{2} \mathrm{Me}$ bearing phenyl ring is expected to be free from the liver toxicities of nimesulide. We also performed the stability studies using the compound $\mathbf{4 1}$ in the presence of $50 \mathrm{mM}$ tris buffer ( $\mathrm{pH} 7.4$ ) initially where $60 \%$ of $\mathbf{4 1}$ was found to remain unchanged after $2 \mathrm{~h}$ incubation in buffer. This study indicated that the present class of compounds perhaps is not susceptible towards rapid ester hydrolysis. Moreover, not being the direct prodrug of nimesulide, these compounds would not provide nimesulide as such after ester hydrolysis. Thus these compounds are expected to be free from the gastric ulceration problem of nimesulide or other NSAIDs (nonsteroidal anti-inflammatory drugs).

Recently, a nimesulide analogue obtained via its chemical modification, that is, replacing the phenyl ether moiety by an aryl ether and the nitro group by a cyclohexyl carboxamide moiety, showed suppression of three breast cancer cell proliferation types in a dose dependent manner [21]. While the anticancer molecular target of this compound was not clearly understood, the cytochrome $c$ release assay indicated that the apoptosis induced by this compound was mediated through the mitochondria. Due to the structural similarities with this compound, present series of glycolamide esters might follow similar cytochrome $c$ dependent mechanisms. Nevertheless, our study indicates that the glycolamide esters derived from nimesulide [28-30] are of further interest.

\section{Conclusions}

In conclusion, we have successfully accomplished the synthesis of several new nimesulide based glycolamide esters via a three-step method starting from nimesulide in good yields. Structures of the synthesized compounds were confirmed 


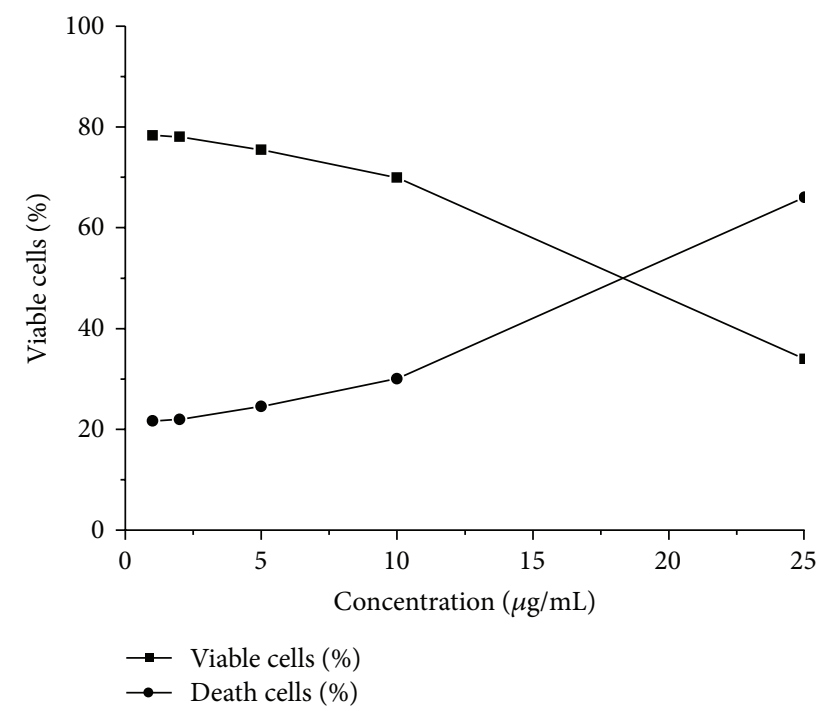

FIGURE 2: Graphical presentation of in vitro cytotoxic activity of compound $\mathbf{4 1}$ against HCT-15 human colon cancer cell line.

by spectroscopic analysis. All the synthesized compounds were examined for their cytotoxic effects in vitro. Some of the compounds showed significant cytotoxic activities against HCT-15 human colon cancer cell line. Overall, the present nimesulide based glycolamide ester framework appeared to be a useful template for the design and identification of novel and potential anticancer agents.

\section{Acknowledgment}

The authors (Kavitha Kankanala and Sarbani Pal) thank Mr. M. N. Raju, the chairman of M. N. R. Educational Trust, for his constant encouragement.

\section{References}

[1] D. M. Parkin, F. Bray, J. Ferlay, and P. Pisani, "Global cancer statistics, 2002," CA Cancer Journal for Clinicians, vol. 55, no. 2, pp. 74-108, 2005.

[2] N. M. Nielsen and H. Bundgaard, "Glycolamide esters as biolabile prodrugs of carboxylic acid agents: synthesis, stability, bioconversion, and physicochemical properties," Journal of Pharmaceutical Sciences, vol. 77, no. 4, pp. 285-298, 1988.

[3] L. K. Wadhwa and P. D. Sharma, "Glycolamide esters of 6methoxy-2-naphthylacetic acid as potential prodrugs-synthetic and spectral studies," Indian Journal of Chemistry, vol. 34, pp. 408-415, 1995.

[4] P. D. Sharma, K. J. Singh, S. Gupta, and S. Chandiran, "Glycolamide esters of 4-biphenylacetic acid as potential prodrugssynthetic and spectral studies," Indian Journal of Chemistry, vol. 43, no. 3, pp. 636-642, 2004.

[5] N. M. Nielsen and H. Bundgaard, "Evaluation of glycolamide esters and various other esters of aspirin as true aspirin prodrugs," Journal of Medicinal Chemistry, vol. 32, no. 3, pp. 727-734, 1989.

[6] A. K. Bansal, R. K. Khar, R. Dubey, and A. K. Sharma, "Activity profile of glycolamide ester prodrugs of ibuprofen," Drug
Development and Industrial Pharmacy, vol. 27, no. 1, pp. 63-70, 2001.

[7] A. K. Gadad, S. Bhat, V. S. Tegeli, and V. V. Redasani, "Synthesis, spectral studies and anti-inflammatory activity of glycolamide esters of niflumic acid as potential prodrugs," ArzneimittelForschung, vol. 52, no. 11, pp. 817-821, 2002.

[8] F. Cao, J.-X. Guo, Q.-N. Ping, and Z.-G. Liao, "Prodrugs of scutellarin: ethyl, benzyl and $N, N$-diethylglycolamide ester synthesis, physicochemical properties, intestinal metabolism and oral bioavailability in the rats," European Journal of Pharmaceutical Sciences, vol. 29, no. 5, pp. 385-393, 2006.

[9] S. Khanna, M. Madan, A. Vangoori et al., "Evaluation of glycolamide esters of indomethacin as potential cyclooxygenase-2 (COX-2) inhibitors," Bioorganic and Medicinal Chemistry, vol. 14, no. 14, pp. 4820-4833, 2006.

[10] C. N. Nalini, S. Ramachandran, K. Kavitha, and V. S. Saraswathi, "Glycolamide esters of naproxen as potential prodrugssynthesis, spectral studies and preliminary pharmacological screening," International Journal of Research in Pharmaceutical and Biomedical Sciences, vol. 2, pp. 1112-1117, 2011.

[11] M. Amblard, M. Rodriguez, and J. Martinez, "N-benzhydrylglycolamide esters (OBg esters) as carboxyl protecting groups in peptlde synthesis," Tetrahedron, vol. 44, no. 16, pp. 5101-5108, 1988.

[12] W. J. Hoekstra, "Orally-active nipecotamide glycolamide esters for the treatment of thrombosis disorder," US patent no US6066651, 2000.

[13] K. H. Boltze and H. Kreisfeld, "On the chemistry of etofenamate, a novel antiinflammatory agent from the series of $\mathrm{N}$ arylanthranilic acid derivatives," Arzneimittel-Forschung, vol. 27, no. 6 b, pp. 1300-1312, 1977.

[14] S. Pericherla, J. Mareddy, D. P. Geetha Rani, P. V. Gollapudi, and S. Pal, "Chemical modifications of nimesulide," Journal of the Brazilian Chemical Society, vol. 18, no. 2, pp. 384-390, 2007.

[15] L. V. Reddy, M. Nakka, A. Suman et al., "Synthesis of novel quinoline analogues of nimesulide: an unusual observation," Journal of Heterocyclic Chemistry, vol. 48, no. 3, pp. 555-562, 2011.

[16] S. Durgadas, V. K. Chatare, K. Mukkanti, and S. Pal, "Palladiummediated synthesis of novel nimesulide derivatives," Applied Organometallic Chemistry, vol. 24, no. 10, pp. 680-684, 2010.

[17] L. V. Reddy, M. Kethavath, M. Nakka et al., "Design and synthesis of novel cytotoxic agents based on combined framework of quinoline and nimesulide," Journal of Heterocyclic Chemistry, vol. 49, no. 1, pp. 80-87, 2012.

[18] K. Kankanala, V. R. Reddy, K. Mukkanti, and S. Pal, "Lewis acid free high speed synthesis of nimesulide-based novel Nsubstituted cyclic imides," Journal of the Brazilian Chemical Society, vol. 21, no. 6, pp. 1060-1064, 2010.

[19] A. Bhattacharya, S. Ghosh, K. Kankanala et al., "Crystal structure and electronic properties of two nimesulide derivatives: a combined X-ray powder diffraction and quantum mechanical study," Chemical Physics Letters, vol. 493, no. 1-3, pp. 151-157, 2010.

[20] K. Kankanala, V. Prakash, K. Mukkanti, V. R. Reddy, and S. Pal, "N-(4-Methylsulfonamido-3-phenoxyphenyl)-9,10-dihydro9,10-ethanoanthracene-11,12-dicarboximide," MolBank, vol. 2011, article M740, 2011.

[21] B. Chen, B. Su, and S. Chen, "A COX-2 inhibitor nimesulide analog selectively induces apoptosis in Her2 overexpressing breast cancer cells via cytochrome c dependent mechanisms," Biochemical Pharmacology, vol. 77, no. 12, pp. 1787-1794, 2009. 
[22] S. Joudieh, M. Lahiani-Skiba, P. Bon, O. Ba, J. M. Le Breton, and M. Skiba, "Nimesulide apparent solubility enhancement with natural cyclodextrins and their polymers," Letters in Drug Design and Discovery, vol. 5, no. 6, pp. 406-415, 2008.

[23] T. Mosmann, "Rapid colorimetric assay for cellular growth and survival: application to proliferation and cytotoxicity assays," Journal of Immunological Methods, vol. 65, no. 1-2, pp. 55-63, 1983.

[24] J. Ferlay, H. R. Shin, F. Bray, D. Forman, C. Mathers, and D. M. Parkin, "Colorectal cancer incidence, mortality and prevalence worldwide in 2008, Summary," in Proceedings of the GLOBOCAN, 2008.

[25] The ALOGPS 2.1 program was used to calculate the average $\log \mathrm{P}$ and average logs values, http://www.vcclab.org/lab/ alogps/start.html.

[26] R. Davis and R. N. Brogden, "Nimesulide. An update of its pharmacodynamic and pharmacokinetic properties, and therapeutic efficacy," Drugs, vol. 48, no. 3, pp. 431-454, 1994.

[27] F. E. Mingatto, A. C. Dos Santos, T. Rodrigues, A. A. Pigoso, S. A. Uyemura, and C. Curti, "Effects of nimesulide and its reduced metabolite on mitochondria," British Journal of Pharmacology, vol. 131, no. 6, pp. 1154-1160, 2000.

[28] B. Su and S. Chen, "Lead optimization of COX-2 inhibitor nimesulide analogs to overcome aromatase inhibitor resistance in breast cancer cells," Bioorganic and Medicinal Chemistry Letters, vol. 19, no. 23, pp. 6733-6735, 2009.

[29] B. Zhong, R. Lama, K. M. Smith, Y. Xu, and B. Su, "Design and synthesis of a biotinylated probe of COX-2 inhibitor nimesulide analog JCC76," Bioorganic and Medicinal Chemistry Letters, vol. 21, no. 18, pp. 5324-5327, 2011.

[30] B. Zhong, X. Cai, S. Chennamaneni et al., "From COX-2 inhibitor nimesulide to potent anti-cancer agent: synthesis, in vitro, in vivo and pharmacokinetic evaluation," European Journal of Medicinal Chemistry, vol. 47, no. 1, pp. 432-444, 2012. 

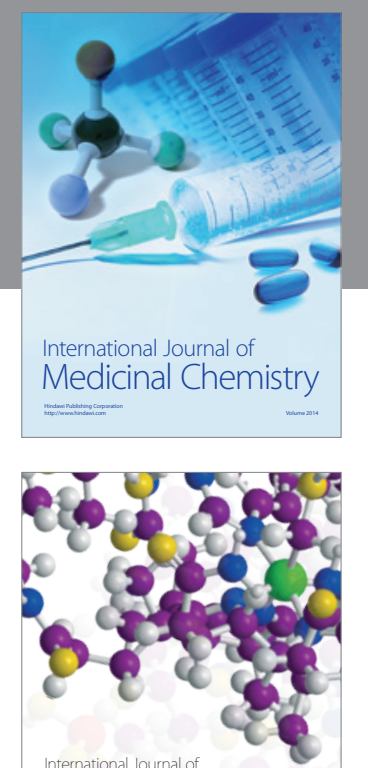

\section{Carbohydrate} Chemistry

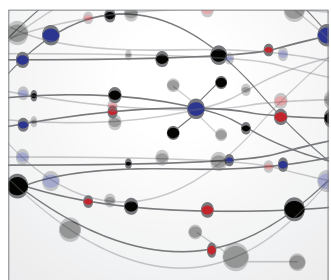

The Scientific World Journal
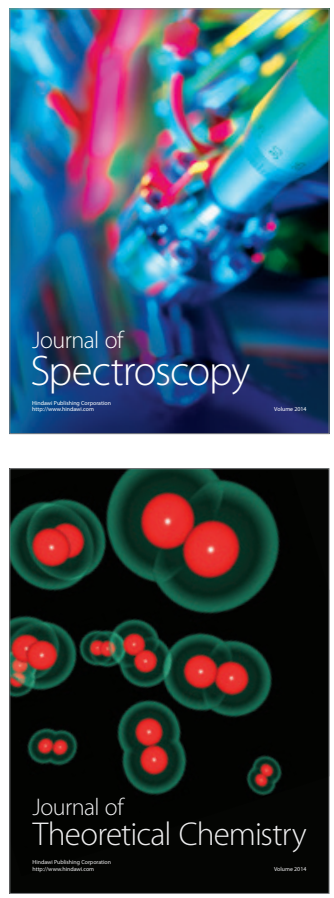
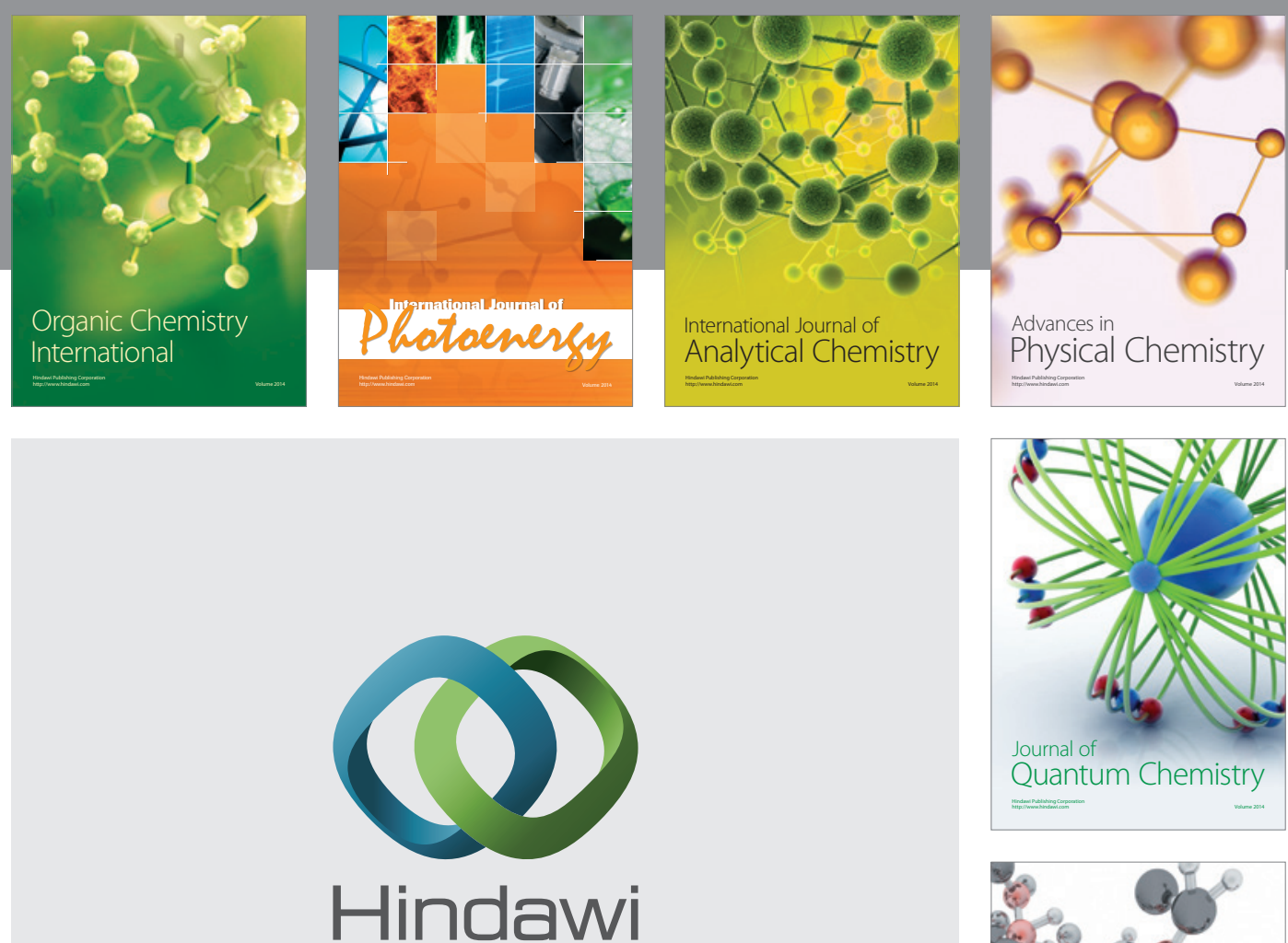

Submit your manuscripts at

http://www.hindawi.com

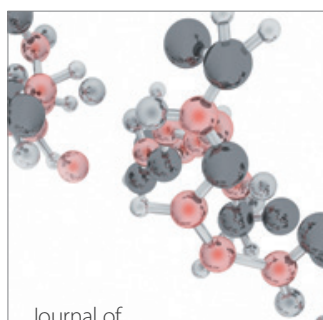

Analytical Methods

in Chemistry

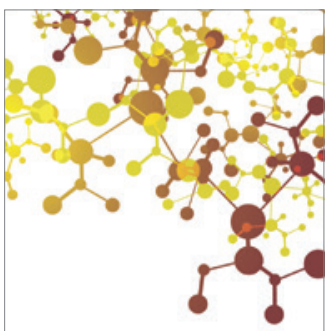

Journal of

Applied Chemistry

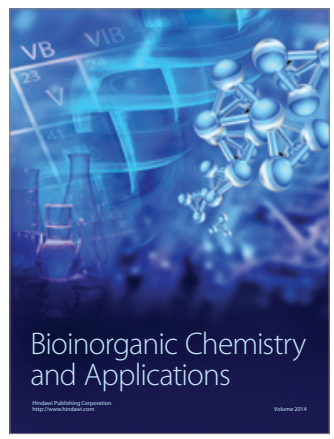

Inorganic Chemistry
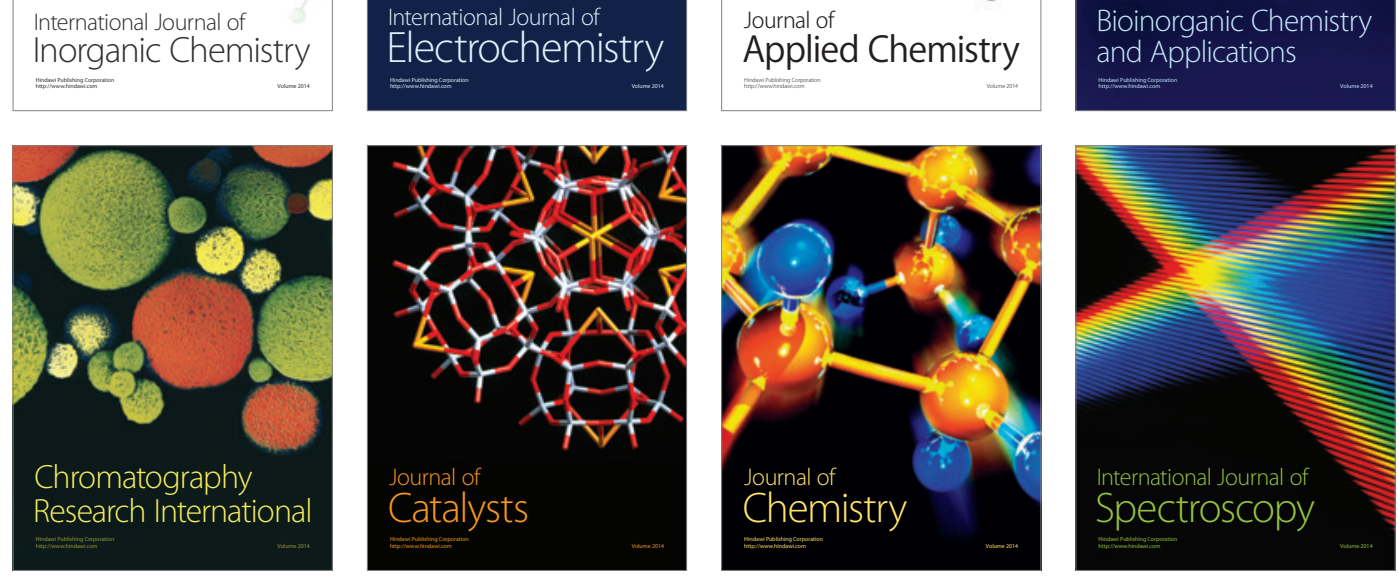